Scientific Journal. ISSN 2595-9433

Volume 3, Number 2, Article n. 4, July/December

D.O.I. http://dx.doi.org/10.35418/2526-4117/v3n2a4

Received: 12/20/2020 - Accepted: 03/14/2021

\title{
EVIDENCE OF ADDITIVE INHERITANCE OF POPPING EXPANSION IN POPCORN
}

\author{
Omar Possatto Júnior ${ }^{1}$, (iD Ronald José Barth Pinto ${ }^{1}$, (iD) Evandrei Santos Rossi ${ }^{1}$, \\ Maurício Carlos Kuki ${ }^{1}$, (D) Filipe Augusto Bengasi Bertagna ${ }^{1}$, (D) Pedro Henrique \\ Araújo Diniz Santos ${ }^{2}$, (D) Carlos Alberto Scapim ${ }^{1 *}$ \\ 1 Departamento de Agronomia - Universidade Estadual de Maringá, 870900-000, Maringá, PR; \\ 2 Laboratório de Melhoramento Genético Vegetal - Centro de Ciências e Tecnologias \\ Agropecuárias - Universidade Estadual do Norte Fluminense Darcy Ribeiro, 28013-602, \\ Campos dos Goytacazes, RJ. \\ *Corresponding author: Carlos Alberto Scapim (cascapim@uem.br)
}

\begin{abstract}
Questions about the faithful inheritance of the trait popping expansion (PE) in popcorn persist even eight decades after the first correlated study was initiated, raising doubts with regard to the best-suited breeding plans to obtain consistent genetic progress. The objective was to fill this scientific gap by implementing a genetic-statistical system based on analyses of segregating and non-segregating generations, for a more thorough examination of the partitioning of the genetic variance components in the expression of popping expansion in popcorn. Four crosses between popcorn (P) and dent corn (D) inbred lines were used [D29.109 x P9.4.6; D70H26.1 x P9.4.6; D60H23.1 x P9.4.6; D53H20.2 x P13] to establish the generations $\mathrm{F}_{1}, \mathrm{~F}_{2}, \mathrm{BC}_{1}$ and $\mathrm{BC}_{2}$, which were evaluated together with the parents at two locations in the Northwest of Paraná, in randomized complete block design with three replications. The parents were chosen for their high divergence in PE to adequately establish generations. Additivity in PE expression was predominant in all crosses and at both locations. Intrapopulation breeding methods are the most suitable for selection gain in PE. Popping expansion can be used as an early predictor of promising inbred lines to obtain superior hybrids for popping expansion. Backcross methods are realistic and should be preferred in popcorn breeding. It is recommended to transfer the PE alleles from popcorn to common maize lines to combine vigor and high popping expansion.
\end{abstract}

Keywords: Generation analysis, variance components, Zea mays var. Everta.

\section{Introduction}

For nearly eight decades since the release of Lyerly's pioneering study (1942), the definition of inheritance of popping expansion (PE) in popcorn has been a matter of controversy. In his classic study, Lyerly showed that the mean of parent inbred lines is equivalent to that of the $F_{1}$ generation, which strongly indicates the influence of additive inheritance on $\mathrm{PE}$ expression. About five decades later, in an analysis of generation means of two popcorn $\times$ dent corn crosses, Dofing et al. (1991) found a PE decrease caused by dominance effects, suggesting that programs that exploit additive variation are the most indicated for PE gains. Shortly afterwards, the study of Larish and Brewbaker (1999) consolidated the possibility of 
prevalence of additivity for PE, by estimating negative heterosis for popping expansion in two diallel mating schemes, one composed of populations as parents and the other using lines as parents. The emphasis of a study of Pereira and Amaral Junior (2001), which implemented Design I of Comstock and Robinson (1948) in the popcorn population UNB-2U, focused on the disclosure of the predominance of additivity in PE expression. In a next step, these authors indicated that the best breeding strategy for greater popping expansion would be an intrapopulation method.

On the other hand, molecular marker studies identified markers associated with QTLs for popping expansion with complete dominance, partial dominance and overdominance effects (Babu et al., 2006; Li et al., 2017), clearly showing the non-exclusivity of additive effects on PE expression. More recently, Oliveira et al. (2018) observed the influence of dominance effects on $\mathrm{PE}$ in a diallel analysis of $\mathrm{S}_{3}$ popcorn lines and recommended the exploitation of heterosis for significant increases in the trait. Moreover, in an attempt to better understand PE inheritance, Coan et al. (2019) established the popcorn $\times$ dent corn cross and stated mixed inheritance in PE expression. In turn, Santos et al. (2020) developed a study to determine the merit and genetic control of leaf diseases in popcorn. To this end, they evaluated eight lines and 56 hybrids, including the reciprocal, derived from a complete diallel mating scheme, and detected the genetic component dominant variance for PE.

This ambiguity in the conception of inheritance of popping expansion generates a gap that strong impacts the advancement of popcorn breeding with regard to the key trait of grain quality. Consequently, the possibility of an advance in the agribusiness of the crop, which accounts for an annual turnover of about 1 billion dollars in the USA and has a high demand in Brazil, is also impaired (Kist et al., 2018). An indication of the most suitable breeding program must be closely associated with reliable knowledge about the trait inheritance.

In spite of increasing gains in popping expansion in intrapopulation breeding programs (Pacheco et al., 1998; Pereira and Amaral Júnior,
2001; Amaral Junior et al., 2013; Vieira et al., 2017; Guimarães et al., 2019), the existence of publications describing dominance effects for $\mathrm{PE}$ must lead to the recommendation of hybrid exploitation with a view to improving the popping expansion (Faria et al., 2008; Viana et al., 2013; Oliveira et al., 2018; Coan et al., 2019; Santos et al., 2020).

In the studies focused on the identification of the expression of popping expansion in popcorn, diallel mating design have commonly been used. In this case, they are disadvantageous, for providing results restricted to the set of parents used, which are usually considered to have fixed effects. In another study on inheritance of popping expansion in popcorn, the nested mating or North Carolina design I was used, which tends to overestimate additive variance (Halluer et al., 2010). The reason is that once different female parents are crossed with the same male parent, the female/male variation source decreases, naturally resulting in a lower dominance deviation estimate (Gouesnard and Gallais, 1992).

A more laborious procedure, which however generates more reliable estimates of variances for inheritance studies, is generation analysis. In this system, the $\mathrm{F}_{1}, \mathrm{~F}_{2}, \mathrm{BC} 1$ and $\mathrm{BC} 2$ generations are usually established and added to the parents (P1 and $\mathrm{P} 2)$. For capitalizing on the variation of different generations, the estimates of the variance components become more accurate (Kearsey e Pooni, 1998; Hallauer et al., 2010).

Generation analysis, to date rarely used in popcorn inheritance studies, was applied in this paper, in an attempt to reliably partition the genetic variance into the components of additive, dominance and epistatic effects. The purpose was to elucidate, by a more reliable procedure, the real participation of these components in the expression of popping expansion in popcorn and, consequently, be able to recommend a more credible breeding plans to ensure consistent gains.

\section{Material and methods}

Six $\mathrm{S}_{8}$ inbred lines (four dent and two popcorn) were used, selected for the study because of the great divergence in popping expansion. Four crosses were made according to the genealogies shown in Table 1. 
Table 1. Genealogy of parent lines for the study of generation analysis of four crosses of dent corn (D) and popcorn (P).

\begin{tabular}{|c|c|c|}
\hline Crosses & Origin - dent (D) maize line & Origin - popcorn line (P) \\
\hline 1 & $\begin{array}{l}29.109 \text { (derived from a cross of } \\
\text { the hybrids Penta x P30F53) }\end{array}$ & $\begin{array}{l}\text { P9.4.6 (derived from the modified } \\
\text { single-cross hybrid IAC 112) }\end{array}$ \\
\hline 2 & $\begin{array}{c}70 \mathrm{H} 26.1 \text { (derived from the single- } \\
\text { cross hybrid P30F33) }\end{array}$ & $\begin{array}{l}\text { P9.4.6 (derived from the modified } \\
\text { single-cross hybrid IAC 112) }\end{array}$ \\
\hline 3 & $\begin{array}{c}60 \mathrm{H} 23.1 \text { (derived from the single- } \\
\text { cross hybrid A 2560) }\end{array}$ & $\begin{array}{l}\text { P9.4.6 (derived from the modified } \\
\text { single-cross hybrid IAC 112) }\end{array}$ \\
\hline 4 & $\begin{array}{c}53 \mathrm{H} 20.2 \text { (derived from the single- } \\
\text { cross hybrid Tork) }\end{array}$ & $\begin{array}{c}\text { GP } 13 \text { (derived from the triple- } \\
\text { cross hybrid Jade) }\end{array}$ \\
\hline
\end{tabular}

During the second growing season of 2015, the F1 generation was established to derive the six generations. All generations were obtained in the first growing season 2015/16, to avoid possible differences in seed quality and vigor in the experiment. Initially, the parents were selfed and crossed, resulting in the parents and F1. With the F1 generation of the previous season, F2 was generated by selfing F1 plants. Backcrosses were made by crossing F1 with the parent lines.

The field for pollination of the parents and F1 plants of the previous season consisted of two $10.00-\mathrm{m}$ rows for each generation, spaced $0.90 \mathrm{~m}$ apart. To ensure coincidence of flowering of the parents, the second row was sown 10 days after the first. The six generations P1, P2, F1, F2, BC1 and $\mathrm{BC} 2$ were established by hand pollination and pollen mixing separately for each generation.

The treatments, consisting of the six generations $\mathrm{P} 1, \mathrm{P} 2, \mathrm{~F} 1, \mathrm{~F} 2, \mathrm{BC} 1$ and $\mathrm{BC} 2$ which were randomized complete blocks design, with three replications. The plots consisting of eight $5.00-\mathrm{m}$ rows, spaced $0.90 \mathrm{~m}$ apart. The evaluated area for parents (P1 and P2) and F1, consisted of one $5.00-\mathrm{m}$ row; of two $5-\mathrm{m}$ rows for the backcross generations (BC11 and $\mathrm{BC} 12)$ and of six 5.00-m rows for $\mathrm{F} 2$. Two trials were carried out in the Northwest of Paraná, namely at: i) Irrigation Technology Center (CTI), of the State University of Maringá (UEM), in Maringá (latitude $23^{\circ} 25^{\prime} \mathrm{S}$, longitude $51^{\circ} 57^{\prime} \mathrm{W} ; 542 \mathrm{~m}$ asl), during the 2nd growing season (2016); and ii) Experimental Farm Iguatemi (FEI - UEM), in the county of Iguatemi-Maringá $\left(23^{\circ} 25^{\prime}\right.$ 'S, longitude $51^{\circ} 57^{\prime} \mathrm{W} ; 550 \mathrm{~m}$ asl), during the $1 \mathrm{st}$ growing season $(2016 / 17)$.
To determine popping expansion (PE), a 30 $\mathrm{g}$ grain sample was microwaved in a kraft paper bag for $2 \mathrm{~min}$; the popcorn volume was measured in a 2,000 $\mathrm{mL}$ beaker, and the popped volume divided by $30 \mathrm{~g}$, and expressed in $\mathrm{mL}$ g-1. For this purpose, 30 ears of the generations P1, P2 and $\mathrm{F} 1$ were used; 180 ears of $\mathrm{BC} 1$ and $\mathrm{BC} 2$; and 540 ears per cross for F2. The data referring to the evaluated traits of each F2 plant were subjected to the Lilliefors normality test, which estimates adherence to the normal curve, based on the mean and deviations from the data set.

We estimated the components of environmental variance $\left(\hat{\sigma}_{\varepsilon}^{2}=\frac{2 \widehat{\sigma}_{F 1}^{2}+\widehat{\sigma}_{P 1}^{2}+\widehat{\sigma}_{P 2}^{2}}{4}\right)$; phenotypic variance $\left(\hat{\sigma}_{f(F 2)}^{2}=\hat{\sigma}_{F 2}^{2}\right) ;$ genetic variance $\left(\hat{\sigma}_{g(F 2)}^{2}=\hat{\sigma}_{f(F 2)}^{2}-\hat{\sigma}_{\varepsilon}^{2}\right)$; additive variance $\left(\hat{\sigma}_{a}^{2}=\right.$ $\left.2 \hat{\sigma}_{f(F 2)}^{2}-\left[\hat{\sigma}_{f(B C 11)}^{2}+\hat{\sigma}_{f(B C 12)}^{2}\right]\right), \quad$ where: $\hat{\sigma}_{g(B C 11)}^{2}=\hat{\sigma}_{f(B C 11)}^{2}-\hat{\sigma}_{\varepsilon(B C 11)}^{2}, \quad \hat{\sigma}_{g(B C 12)}^{2}=$ $\hat{\sigma}_{f(B C 12)}^{2}-\hat{\sigma}_{\varepsilon(B C 12)}^{2}, \quad \hat{\sigma}_{\varepsilon(B C 11)}^{2}=\frac{\widehat{\sigma}_{F 1}^{2}+\widehat{\sigma}_{P 1}^{2}}{2}$ and $\hat{\sigma}_{\varepsilon(B C 12)}^{2}=\frac{\widehat{\sigma}_{F 1}^{2}+\widehat{\sigma}_{P 2}^{2}}{2}$ dominance variance $\left(\hat{\sigma}_{d}^{2}=\right.$ $\left.\hat{\sigma}_{g(F 2)}^{2}-\hat{\sigma}_{a}^{2}\right) ;$ heterosis $\left(\mathrm{h}=\left[\frac{\bar{F}_{1}-\bar{P}_{2}}{\bar{P}_{12}}\right] X 100\right)$; narrow-sense heritability $\left(h_{r}^{2}=\frac{\widehat{\sigma}_{a}^{2}}{\widehat{\sigma}_{f}^{2}} \times 100\right)$; average degree of dominance (ADD) and number of genes that control the trait $\left(n=\left[\left(R^{2}(1+\right.\right.\right.$ $\left.\left.0.5 k^{2}\right)\right] / 8 \hat{\sigma}_{g}^{2}$ ), where $\mathrm{R}^{2}$ is the total amplitude in $\mathrm{F}_{2}$ and $\mathrm{k}=\mathrm{ADD}$.

To analyze the genetic effects, the effects of the means of all possible homozygotes $(\widehat{m}=$ $\left.\frac{1}{2} \bar{P}_{1}+\frac{1}{2} \bar{P}_{2}+4 \bar{F}_{2}-2 \overline{B C}_{1}-2 \overline{B C}_{2}\right) ; \quad$ additive $\left(\hat{a}=\frac{1}{2} \bar{P}_{1}-\frac{1}{2} \bar{P}_{2}\right) ;$ dominant $\left(\hat{d}=\frac{3}{2} \bar{P}_{1}-\frac{3}{2} \bar{P}_{2}-\right.$ $\left.\bar{F}_{1}-8 \bar{F}_{2}+6 \overline{B C}_{1}+6 \overline{B C}_{2}\right)$; and epistatic: addi- 
tive $\mathrm{x}$ additive (ââ $=-4 \overline{\mathrm{F}}_{2}+2 \overline{\mathrm{BC}}_{1}+2 \overline{\mathrm{BC}}_{2}$ ), additive $\mathrm{x}$ dominant $\left(\hat{\mathrm{a}} \hat{d}=-\bar{P}_{1}+\bar{P}_{2}+2 \overline{B C}_{1}-\right.$ $\left.2 \overline{B C}_{2}\right)$ and dominant $\mathrm{x}$ dominant effects $(\hat{d} \hat{d}=$ $\left.\bar{P}_{1}+\bar{P}_{2}+2 \bar{F}_{1}+4 \bar{F}_{2}-4 \overline{B C}_{1}-4 \overline{B C}_{2}\right)$. were estimated as proposed by Mather and Jinks (1974).

The goodness-of-fit of the model was tested by the Gaussian elimination method. The effects of both models were subjected to the t-test at $1 \%$ and $5 \%$ probability. Statistical analyses were performed using software Genes (Cruz, 2016).

\section{Results and discussion}

After data normality for popping expansion (PE) in $\mathrm{F}_{2}$ was confirmed by the Lilliefors normality test (data not shown), the analysis of the segregating and non-segregating generation was continued. There was a significant effects of the generations, $p<0,05$, for the four crosses, in two locations, for the popping expansion (Tabela 2).

Table 2. Number of plants (PLA), means and variance estimates $\left(\widehat{\boldsymbol{\sigma}}^{2}\right)$ for popping expansion of six generations derived from crosses between dent corn (D) and popcorn (P) evaluated in two locations (CTI and FEI) in the Northwest of Paraná.

\begin{tabular}{|c|c|c|c|c|c|c|c|c|c|c|c|c|}
\hline & \multicolumn{3}{|c|}{ D29.109 x P9.4.6 } & \multicolumn{3}{|c|}{ D70H26.1 x P9.4.6 } & \multicolumn{3}{|c|}{ D60H23.1 x P9.4.6 } & \multicolumn{3}{|c|}{ D53H20.2 x P 13} \\
\hline & \multicolumn{3}{|c|}{ CTI 1} & \multicolumn{3}{|c|}{ CTI 2} & \multicolumn{3}{|c|}{ CTI 3} & \multicolumn{3}{|c|}{ CTI 4} \\
\hline & PLA & Means & $\widehat{\sigma}^{2}$ & PLA & Means & $\widehat{\boldsymbol{\sigma}}^{2}$ & PLA & Means & $\widehat{\sigma}^{2}$ & PLA & Means & $\widehat{\boldsymbol{\sigma}}^{2}$ \\
\hline $\mathbf{P}_{1(\mathrm{D})}$ & 30 & 3.16 & 0.06 & 30 & 7.69 & 0.57 & 30 & 3.03 & 0.19 & 30 & .24 & 0.88 \\
\hline $\mathbf{P}_{2}(\mathbf{P})$ & 30 & 32.43 & 8.36 & 30 & 25.53 & 0.37 & 30 & 22.95 & 5.29 & 30 & 21.91 & 6.19 \\
\hline$F_{1}$ & 30 & 7.49 & 1.07 & 30 & 49 & 2.35 & 30 & 3.38 & 62 & 30 & .80 & 0.61 \\
\hline $\mathbf{F}_{2}$ & 531 & 9.15 & 25.29 & 522 & 13.79 & 41.37 & 522 & 6.57 & 21.37 & 528 & 11.69 & 41.79 \\
\hline $\mathbf{R C}_{1}$ & 180 & 3.99 & 3.37 & 180 & 7.90 & 11.38 & 180 & 3.45 & 1.52 & 180 & 9.76 & 20.96 \\
\hline \multirow[t]{2}{*}{$\mathrm{RC}_{2}$} & 180 & 19.12 & 23.24 & 180 & 19.56 & 39.57 & 180 & 15.63 & 11.12 & 180 & 17.72 & 33.68 \\
\hline & \multicolumn{2}{|c|}{ FEI 1} & & & \multicolumn{2}{|c|}{ FEI 2} & \multicolumn{3}{|c|}{ FEI 3} & & \multicolumn{2}{|c|}{ FEI 4} \\
\hline$P_{1}$ (D) & 30 & 4.42 & 1.50 & 30 & 5.01 & 1.21 & 30 & 6.08 & 1.93 & 30 & 6.56 & 1.82 \\
\hline$P_{2(P)}$ & 30 & 34.67 & 14.00 & 30 & 38.52 & 4.55 & 30 & 39.64 & 8.98 & 30 & 37.98 & 3.26 \\
\hline$F_{1}$ & 30 & 11.48 & 4.79 & 30 & 10.59 & 3.20 & 30 & 9.23 & 2.08 & 30 & 17.23 & 6.03 \\
\hline$F_{2}$ & 540 & 16.49 & 55.99 & 530 & 17.26 & 55.57 & 531 & 13.49 & 57.35 & 531 & 13.12 & 43.64 \\
\hline $\mathbf{R C}_{1}$ & 180 & 8.36 & 17.72 & 180 & 10.72 & 22.19 & 180 & 7.22 & 11.36 & 180 & 9.21 & 17.07 \\
\hline $\mathrm{RC}_{2}$ & 180 & 27.81 & 45.16 & 180 & 27.28 & 56.98 & 180 & 24.02 & 61.23 & 180 & 25.88 & 50.45 \\
\hline
\end{tabular}

$\mathrm{D}$ : dent; P: popcorn; and BC: backcrosses

The highest phenotypic variance for PE in the $F_{2}$ generation was naturally expected, due to the segregation and recombination of the genes. This underlines the reliability of our results, since it is the first segregating generation and therefore the expression of linkage disequilibrium is strong (Table 2). A good inbred line popping expansion (PE) should have a mean estimate of at least 30 $\mathrm{mL} \mathrm{g}^{-1}$. Therefore, the lines proved divergent for PE, with low mean estimates for the parents D29.109, D70H26.1, D60H23.1 and D53H20.2 (dent corn) and high for the parents P9.4.6 and P 13 (popcorn), confirming the reliability of the high contrast between the parents, which had been pre-selected for their origin from different genealogies. In this context, if the parents are not sufficiently divergent, the biometric interprettations become compromised, since the environ- ments effect will be high, biasing the estimates of the genetic components.

The backcrosses tended to be more similar to the recurrent parental, as expected, since the contribution of favorable and unfavorable alleles to the trait depends on the inbred line used. The mean PE of the backcrosses of the popcorn inbred line was high (Table 2), demonstrating that only one backcross was sufficient to recover approximately $75 \%$ of the PE of the recurrent parent.

The genetic effects based on the means showed that the additive-dominant model with three estimators $(\hat{m}, \hat{a}, \hat{d})$ was goodness-of-fit test (observed means compared with predicted means) to determine the sufficiency and significant, $p<0,01$, of the model to explain the genetic effects of $\mathrm{PE}$ of all crosses in both 
locations (Table 3). Based on the fact the goodness-of-fitstatistic additive-dominant model can be assumed when it explains more than $90 \%$ the differences among the generations means to PE, the epistatic effects in PE expression would be negligible.

The high estimates of the total coefficient of determination $\left(\mathrm{R}^{2}\right)$ of the additive-dominant model warrant a clear additive-dominant expression in all crosses (D29.109 x P9.4.6; D70H26.1 x P9.4.6; D60H23.1 x P9.4.6; D53H20.2 x P 13) in the tested locations. The significance of the additive-dominant model minimizes the importance of the epistatic components and highlights the additive and dominance effects, but not only the additive effects.

Environmental variance was estimated from data of non-segregating generations (P1, P2 and $F_{1}$ ) of each cross, in each location (Table 4). It varied from 3.40 to $11.20 \%$ of the phenotypic variance, showing that genetic variance, which can be partitioned into additive and non-additive effects, accounted for the largest effect of phenotypic variance.

Table 3. Gene effects for the additive-dominant model of segregating generations derived from a crosses between dent corn (D) and popcorn (P) inbred lines.

\begin{tabular}{|c|c|c|c|c|c|c|c|c|}
\hline \multirow[b]{2}{*}{ Effects } & \multicolumn{2}{|c|}{$\begin{array}{c}\text { D29.109 x P9.4.6 } \\
\text { CTI1 }\end{array}$} & \multicolumn{2}{|c|}{$\begin{array}{c}\mathrm{D} 70 \mathrm{H} 26.1 \text { x P9.4.6 } \\
\text { CTI } 2\end{array}$} & \multicolumn{2}{|c|}{$\begin{array}{c}\mathrm{D} 60 \mathrm{H} 23.1 \times \mathrm{P} 9.4 .6 \\
\mathrm{CTI} 3\end{array}$} & \multicolumn{2}{|c|}{$\begin{array}{c}\text { D53H20.2 x P } 13 \\
\text { CTI } 4\end{array}$} \\
\hline & Est. & $\mathbf{R}^{2}$ & Est. & $\mathbf{R}^{2}$ & Est. & $\mathbf{R}^{2}$ & Est. & $\mathbf{R}^{2}$ \\
\hline$\widehat{\boldsymbol{m}}$ & $16.64^{* *}$ & 53.59 & $16.69^{* *}$ & 75.95 & $13.41^{* *}$ & 52.57 & $15.25^{* *}$ & 78.38 \\
\hline$\widehat{a}$ & $-13.53^{* *}$ & 35.51 & $-8.96^{\star *}$ & 21.82 & $-10.38^{* *}$ & 32.25 & $-7.00^{* *}$ & 15.64 \\
\hline$\widehat{d}$ & $-10.47^{* \star}$ & 10.88 & $-8.26^{* *}$ & 2.23 & $-9.93^{* *}$ & 15.18 & $-5.41^{* *}$ & 5.97 \\
\hline \multirow[t]{2}{*}{$\mathbf{R}^{2}$} & & 0.99 & & 0.97 & & 0.98 & & 0.97 \\
\hline & \multicolumn{2}{|c|}{ FEI 1} & \multicolumn{2}{|c|}{ FEI 2} & \multicolumn{2}{|c|}{ FEI 3} & \multicolumn{2}{|c|}{ FEI 4} \\
\hline Effects & Est. & $\mathbf{R}^{2}$ & Est. & $\mathbf{R}^{2}$ & Est. & $\mathbf{R}^{\mathbf{2}}$ & Est. & $\mathbf{R}^{2}$ \\
\hline$\widehat{\boldsymbol{m}}$ & $20.86^{* *}$ & 59.27 & $22.20^{\star \star}$ & 61,43 & $22.14^{\star *}$ & 58.79 & $21.35^{* *}$ & 63.58 \\
\hline$\widehat{a}$ & $-16.46^{* *}$ & 37.30 & $-16.83^{* *}$ & 34,66 & $-16.35^{* *}$ & 31.38 & $-15.54^{* *}$ & 34.19 \\
\hline$\widehat{d}$ & $-8.53^{\star *}$ & 3.41 & $-10.28^{* *}$ & 3,90 & $-13.48^{* *}$ & 9.82 & $-8.60^{* *}$ & 2.23 \\
\hline $\mathbf{R}^{2}$ & & 0.98 & & 0.99 & & 0.99 & & 0.95 \\
\hline
\end{tabular}

${ }^{* *}$ t test significant at $1 \%$ level. Est.: Estimate, mean $(\widehat{m})$, additive $(\hat{a})$ and dominance $(\hat{d})$

Table 4. Estimates of the genetic parameters (GP) of popping expansion of generations of crosses between inbred lines of dent corn (D) and popcorn (P), evaluated in two locations (CTI and FEI) in the Northwest of Paraná.

\begin{tabular}{ccccccccc}
\hline \multirow{2}{*}{ GP } & \multicolumn{2}{c}{ D29.109 x P9.4.6 } & \multicolumn{2}{c}{ D70H26.1 x P9.4.6 } & \multicolumn{2}{c}{ D60H23.1 x P9.4.6 } & \multicolumn{2}{c}{ D53H20.2 x P 13 } \\
& CTI 1 & FEI 1 & CTI 2 & FEI 2 & CTI 3 & FEI 3 & CTI 4 & FEI 4 \\
\hline$\widehat{\boldsymbol{\sigma}}_{\boldsymbol{f}}^{2}$ & 25.29 & 55.99 & 41.37 & 55.57 & 21.37 & 57.35 & 41.79 & 43.64 \\
\hline$\widehat{\boldsymbol{\sigma}}_{\varepsilon}^{2}$ & 2.64 & 6.27 & 1.41 & 3.04 & 1.68 & 3.77 & 2.07 & 4.29 \\
\hline$\widehat{\boldsymbol{\sigma}}_{\boldsymbol{g}}^{2}$ & 22.65 & 49.72 & 39.96 & 52.53 & 19.69 & 53.58 & 39.71 & 39.35 \\
\hline$\widehat{\boldsymbol{\sigma}}_{\boldsymbol{a}}^{2}$ & 23.97 & 49.09 & 31.78 & 31.97 & 30.11 & 42.11 & 28.93 & 19.76 \\
\hline$\widehat{\boldsymbol{\sigma}}_{\boldsymbol{d}}^{2}$ & 0.00 & 0.63 & 8.17 & 20.55 & 0.00 & 11.47 & 10.78 & 19.59 \\
\hline$\widehat{\boldsymbol{h}}_{\boldsymbol{r}}^{2}(\%)$ & 94.77 & 87.69 & 76.83 & 57.53 & 100.00 & 73.43 & 69.24 & 45.28 \\
\hline Heterosis (\%) & -57.92 & -41.27 & -54.92 & -51.29 & -74.00 & -59.61 & -34.99 & -22.61 \\
\hline ADD (Variance) & 0.00 & 0.16 & 0.72 & 1.13 & 0.00 & 0.74 & 0.86 & 1.41 \\
\hline $\mathbf{N}^{*}$ of genes & 4 & 4 & 5 & 5 & 3 & 4 & 4 & 6 \\
\hline
\end{tabular}

*Values between 0 and 1 estimated parcial dominance, and higher than 1 estimated overdominance, $\hat{h}_{r}^{2}(\%)$ : narrow-sense heritability, ADD: average degree of dominance and $\mathrm{N}^{\circ}$ of genes: number of genes that control the trait 
Negative heterosis for PE in $F_{1}$, as observed in all crosses and locations, is undesirable (Table 4). Negative heterosis is probably being observed due to the trend of dominance of the lower value (dent) parent over the higher value (popcorn type). Negative heterosis estimates were also reported by Larish and Brewbaker (1999), in an evaluation of parents and $F_{1}$ of a diallel between populations and between popcorn lines. However, positive heterosis was reported in PE expression, e.g. by Scapim et al. (2002), who observed fluctuations in the signs of heterosis estimates in a diallel with popcorn varieties, which proves the occurrence of bidirectional dominance in the trait expression. Positive heterosis for PE was also reported by Faria et al. (2008), in a proposal of the use of reciprocal recurrent selection in popcorn breeding.

The analysis of genetic variance showed that the additive effect was most relevant for the crosses D29.109 x P9.4.6, D70H26.1 x P9.4.6, D60H23.1 x P9.4.6, and D53H20.2 x P 13, in both locations. Using only popcorn as parents, studies by Pereira and Amaral Júnior (2001), Scapim et al. (2006) and Silva et al. (2010) demonstrate the relevance of additivity in the expression of genetic variation for popping expansion.

However, more recently, in some cases, a contribution of the dominance effect to trait expression was also observed, albeit to a lesser extent. This can be explained by the fact that according to the germplasm, the dominance effects may or may not influence the expression of popping expansion.

Popping expansion is believed to be an oligogenic trait (Doffing et al., 1991) with high heritability (Pereira and Amaral Junior, 2001; Arnholdt et al., 2009), controlled by three to five major genes (Ziegler et al., 2001; Lu et al., 2003; Senhorinho et al., 2019). Consequently, the genotypic variation due to environmental factors of this trait is low. Not coincidentally, Yu-Ling et al. (2006) observed little phenotypic variation between genotypes in an investigation of the consistency of QTL for PE in hybrids in different environments, regardless of the different growing seasons.
The estimates of narrow-sense heritability were higher than $45 \%$, therefore, considered medium to high (Hallauer et al., 2010). These magnitudes are consistent with those estimated in the study of Robbins and Ashman (1984) who reported high heritability values for $\mathrm{PE}$ in an evaluation of the $F_{2}$ and $F_{3}$ generations derived from popcorn lines crossed with dent and flint corn. When using the Design I mating system (Nested Design) for the popcorn population UNB-2U, Pereira and Amaral Junior (2001) also obtained an extremely high estimate of narrowsense heritability $(87.72 \%)$.

The heterosis estimate was negative in all crosses and locations, showing that dominance has the effect of decreasing the trait value, confirming the evidence cited in the differences between the line means of $F_{1}$ and $F_{2}$ (Table 4). These observations reinforce the study results of Arnhold et al. (2010), who identified negative dominance in PE control. This favors the premise of the typically additive inheritance for popping expansion, although not exclusively additive, since bidirectional dominance was reported by Scapim et al. (2002) and positive heterosis by Faria et al. (2008). More recently, based on the popcorn $\times$ dent corn cross, Coan et al. (2019) suggested the occurrence of mixed inheritance involving additivity and dominance in the control of expression of $\mathrm{PE}$, although with predominance of additive gene effects.

It was possible to conclude, for two crosses, that it was a perfect additive gene action and all the crosses the estimated additive variance was higher than to dominance variance (Table 4). It was possible to verify the partial dominance variance to some crosses. In summary, the additive variance predominated in all the crosses, with a minor contribution from dominance variance.

The estimated number of genes indicates that PE is controlled by few $(3-6)$ genes in the tested crosses and locations (Table 4), which reinforces that the trait is oligogenic. The assumption of oligogeny was further corroborated by Johnson and Eldredge (1953) in an analysis of crosses of several popcorn with dent corn inbred lines, who found that PE can be 
recovered with two backcrosses followed by selection, indicating that the trait is controlled by a small number of genes.

Oligogeny inheritance associated with predominant additivity in the expression of $\mathrm{PE}$ reinforces the assertion that simple methods of intrapopulation breeding ensure consistent gains for the trait, such as stratified mass or half-sib selection methods, for example. On the other hand, considering the negligible effect of dominance on PE expression but bearing in mind its strong influence on grain yield (GY) (Lyerle, 1942; Larish and Brewbaker, 1991; Pereira and Amaral Junior, 2001; Scapim et al., 2002; Gerhardt et al., 2019, and remembering that for popcorn, simultaneous gains for PE and GY are interesting, it is possible to conclude that interpopulation breeding methods are most convenient for the crop.

In addition, due to the inheritance pattern of popping expansion, this trait can be recommended as a predictor for the elimination of inbred lines in early selfing generations, avoiding the maintenance of unpromising inbred lines to crosses. Finally, to obtain vigorous inbred lines with high PE, the backcross method involving crosses of common maize, dent or flint, with popcorn lines is strongly recommended, in which the PE is easily recovered in only two or three generations of conventional backcrosses, without requiring techniques of molecular markers at the DNA level.

\section{Conclusions}

Intrapopulation methods are recommended for the development of open-pollinated varieties with high popping expansion.

Popping expansion can be used as an early predictor of promising lines to obtain superior hybrids for popping expansion.

Popping expansion is easily recovered in backcrosses involving the cross of common maize with a popcorn line.

\section{References}

AMARAL JÚNIOR, A.T.; GONÇALVES, L.S.A.; FREITAS JÚNIOR, S.P.; CANDIDO, L.S.; VITTORAZZI, C.; PENA, G.F.; RIBEIRO, R.M.; CONCEIÇÃO SILVA, T.R.; PEREIRA, M.G.; SCAPIM, C.A.; VIANA, A.P.; CARVALHO, G.F. 2013. UENF 14: A new popcorn cultivar. Crop Breeding and Applied Biotechnology, 13:218-220.

ARNHOLD, E.; SILVA, R.G.; VIANA, J.M.S. 2010. Seleção de linhagens S $_{5}$ de milho-pipoca com base em desempenho e divergência genética. Acta Scientiarum. Agronomy, 32(2):279-283.

BABU, R.; NAIR, S.K., KUMAR, A.; RAO, H.S.; VERMA, P.; GAHALAIN, A., SOMGH, I.S.; GUPTA, H.S. 2006. Mapping QTLs for popping ability in a popcorn $x$ flint corn cross. Theoretical and Applied Genetics, 112:1392-1399.

BORÉM, A.; MIRANDA, G.V. 2013. Melhoramento de Plantas. 6 ${ }^{\text {a }}$ ed. Viçosa: Editora UFV, $527 \mathrm{p}$.

CABRAL, P.D.S.; AMARAL JÚNIOR, A.T.; FREITAS, I.L.J.; RIBEIRO, R.M.; SILVA, T.R.C. 2016. Relação causa e efeito de caracteres quantitativos sobre a capacidade de expansão do grão em milho-pipoca. Revista Ciência Agronômica, 47(1):108-117.

COAN, M.M.D.; Barth, R.J.P.; KUKI, M.C.; AMARAL JUNIOR, A.T.A.; FIGUEIREDO, A.S.T.; SCAPIM, C.A.; WARBURTON, M. 2019. Inheritance study for popping expansion in popcorn vs. flint corn genotypes. Agronomy Journal, 111:1-10.

COMSTOCK, R.E.; ROBINSON, H.F. 1948. The components of genetic variance in populations of biparental progenies and their use in estimating the average degree of dominance. Biometrics, $4: 254-266$. 
CRUZ, C.D. 2016._Genes Software - extended and integrated with the R, Matlab and Selegen. Acta Scientiarum.Agronomy, 38:547-552.

CRUZ, C.D.; REGAZZI, A.J.; CARNEIRO, C.S. 2014. Modelos biométricos aplicados ao melhoramento genético. $3^{\mathrm{a}}$ ed. Viçosa: Editora UFV. 668p.

DOFING, S.M.; D“CROZ-MASON, N.; THOMAS-COMPTON, M.A. 1991. Inheritance of expansion volume and yield in two popcorn x dent corn crosses. Crop Science, 31(3):715-718.

FARIA, G.M.P. 2012. Controle genético do teor de óleo em sementes de algodão (Gossypium spp). Viçosa: Universidade Federal de Viçosa. Dissertação (Mestrado em Genética e Melhoramento de Plantas). 73 p.

FARIA, V.R.; VIANA, J.M.S.; SOBREIRA, F.M.; SILVA, A.C. 2008. Seleção recorrente recíproca na obtenção de híbridos interpopulacionais de milho-pipoca. Pesquisa Agropecuária Brasileira, 43(12):1749-1755.

GERHARDT, I.F.S.; AMARAL JÚNIOR, A.T., PENA, G.F.; GUIMARÃES, L.J.M.; LIMA, V.J. VIVAS, M.; SANTOS, P.H.D.; FERREIRA, F.R.A.; MENDONÇA, M.S.F.; KAMPHORST, S.H. 2019. Genetic effects on the efficiency and responsiveness to phosphorus use in popcorn as estimated by diallel analysis. PLOS ONE, 14:1-14.

GOUESNARD, B.; GALLAIS, A. 1992. Genetic variance component estimation in a nested mating design with positive assortative mating, and application to maize. Crop Science, 32:1127-1131.

GUIMARÃES, A.G.; AMARAL JÚNIOR, A.T.; PENA, G.F.; ALMEIDA FILHO, J.E.D.; PEREIRA, M.G.; SANTOS, P.H.A.D. 2019. Genetic gains in the popcorn population uenf-14: developing the ninth generation of intrapopulation recurrent selection. Caatinga, 32(3):625633.

HALLAUER, A.R.; CARENA, M.J.; MIRANDA FILHO, J.D. 2010. Testers and combining ability. In: Springer New York. Quantitative genetics in maize breeding. p. 383-423.

JOHNSON, I.J.; ELDREDGE, J.C. 1953. Performance of recovered popcorn inbred lines derived from outcrosses to dent corn. Agronomy Journal, 45:105-110.

KEARSEY, M.J.; POONI, H.S. 1998. The genetical analysis of quantitative traits. London: Chapman and Hall. 381p.

KIST, B.B.; FILTER, F.C.; SANTOS, C.E.; CARVALHO, C. 2018. Anuário brasileiro do milho. Santa Cruz do Sul: Editora Gazeta Santa Cruz. 88p.

LARISH, L.B., BREWBAKER, J.L. 1999. Diallel analyses of temperate and tropical popcorn. Maydica, 44:279-284.

LI, Y.L.; DONG, Y.B.; NIU, S.Z.; CUI, D.Q. 2007. QTL for popping characteristics in popcorn. Plant Breeding. 126:509-514.

LOPES, M.T.G.; LOPES, R.; BRUNELLI, K.R.; SILVA, H.P.; MATIELLO, R.R.; CAMARGO, L.E.A. 2007. Controle genético da resistência à mancha-de-Phaeosphaeria em milho. Ciência Rural, 37(3):605-611. 
LYERLY, P.J. 1942. Genetic and morphologic characters affecting the popping expansion of popcorn. Ames: Iowa State University. Thesis (Philosofy of Doctor in Plant Breeding). 81p.

MATHER, R.K.; JINKS, J.L. 1974. Biometrical Genetics: The study of continuous variation. $2^{\text {a }}$ ed. New York: Cornell University Press, Ithaca. 382p.

OLIVEIRA, G.H.F.; AMARAL, C.B.; REVOLTI, L.T.M.; BUZINATO, R.; MORO, G.V. 2018. Genetic variability in popcorn synthetic population. Acta Scientiarum.Agronomy, 41:1-9.

PACHECO, C.A.P.; GAMA, E.E.G.; GUIMARÃES, P.E.O.; SANTOS, M.X.; FERREIRA, A.S. 1998. Estimativas de parâmetros genéticos nas populações CMS-42 e CMS-43 de milhopipoca. Pesquisa Agropecuária Brasileira, 33:1995-2001.

PEREIRA, M.G.; AMARAL JÚNIOR, A.T. 2001. Estimation of Genetic components in popcorn based on nested design.Crop Breeding and Applied Biotechnology, 1(1):3-10.

PINTO, R.J.B.; SCAPIM, C.A.; BARRETO, R.R.; RODOVALHO, M.A.; ESTEVES, N.; LOPES, A.D. 2007. Análise dialélica de linhagens de milho-pipoca. Revista Ceres, 54:471-477.

ROBBINS, W.A.; ASHMAN, R.B. 1984. Parent off spring popping expansion correlation in progeny of dent x popcorn crosses. Crop Science, 24:119-121.

SANTOS, J.S.; SOUZA, Y.P.; VIVAS, M.; AMARAL JÚNIOR, A.T.; ALMEIDA FILHO, J.E.; MAFRA, G.S.; VIANA, A.P.; GRAVINA, G.A.; FERREIRA, F.R.A. 2020. Genetic merit of popcorn lines and hybrids for multiple foliar diseases and agronomic properties. Functional Plant Breeding Journal, 2(2): 33-47.

SENHORINHO, H.J.C. ; COAN, M.M.D. ; MARINO, T.P. ; KUKI, M.C. ; PINTO, R. J. B.; SCAPIM, C.A.; HOLLAND, J.B. 2019. Genomic-Wide Association Study of Popping Expansion in Tropical Popcorn and Field Corn Germplasm. Crop Science, 59: 2007-2019.

SCAPIM, C.A.; BRACCINI, A.L.; PINTO, R.J.B.; AMARAL JÚNIOR, A.T.; RODOVALHO, M.A.; SILVA, R.M.; MORTELE, L.M. 2006. Componentes genéticos de médias e depressão por endogamia em populações de milho-pipoca. Ciência Rural, 36:34-41.

SCAPIM, C.A.; PACHECO, C.A.P.; TONET, A.; BRACCINI, A.L.; PINTO, R.J.B. 2002. Análise dialélica e heterose de populações de milho-pipoca. Bragantia, 61(3):219-230.

SILVA, V.Q.R.; AMARAL JÚNIOR, A.T.; SCAPIM, C.A; FREITAS JÚNIOR, S.P.; GONÇALVES, L.S.A. 2010. Inheritance for economically important traits in popcorn from distinct heterotic groups by Hayman's diallel. Cereal Research Communications, 38(2):272-284.

STANSFIELD, W. D. 1974. Genética. São Paulo: McGraw-Hill do Brasil. 958p.

VIANA, J.M.S.; LIMA, R.O.; MUNDIM, G.B.; CONDÉ, A.B.T.; VILARINHO, A.A. 2013. Relative efficiency of the genotypic value and combining ability effects on reciprocal recurrent selection. Theoretical and Applied Genetics, 126:889-899.

VIEIRA, R.A.; ROCHA, R.; ALBERTO, C.; AMARAL JÚNIOR, A.T. 2017. Recurrent selection of popcorn composites UEM- CO1 and UEM-CO2 based on selection indices. Crop Breeding and Applied Biotechnology, 17:266-272. 